\title{
Evaluation of Antimicrobial Activity and Qualitative Phytochemical Screening of solvent extracts of Dalbergia melanoxylon (Guill. \& Perr.)
}

\author{
E. Amri* and S. Juma \\ Department of Science and Laboratory Technology, Dar es Salaam Institute of Technology, \\ P. O. Box 2958, Dar es Salaam, Tanzania \\ *Corresponding author
}

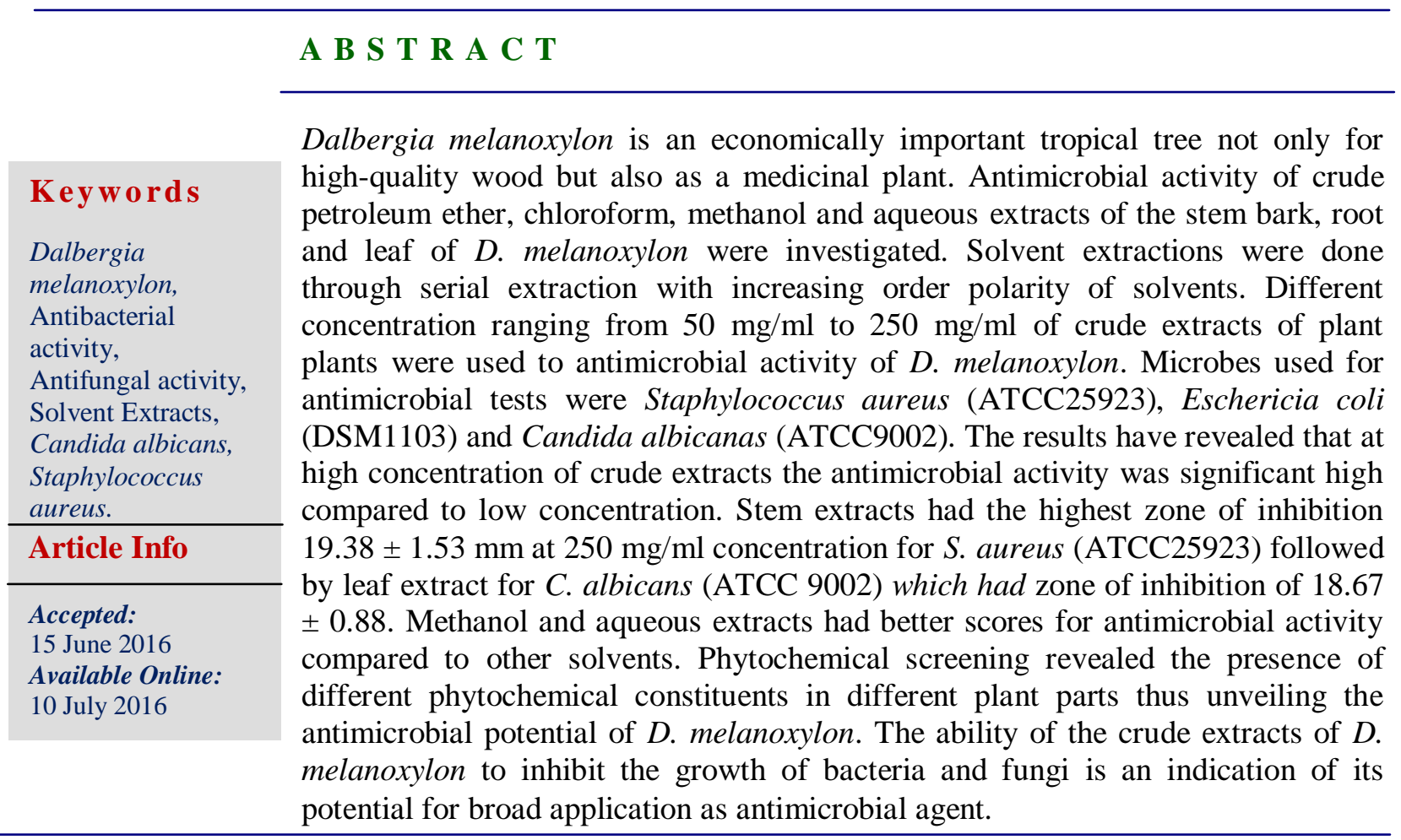

\section{Introduction}

Dalbergia melanoxylon Gill. \& Perr. known as African Blackwood or Mpingo in Swahili is a flowering plant in the family Fabaceae known to be an economically important tree with high-quality wood and being one of the most expensive timbers in the world (Jenkins et al. 2002, Ball, 2004). D. melanoxylon presently exploited for international trade is the most precious heartwood in the world (Ball, 2004). The tree is uses for making excellent timber and locally in Tanzania used for making woodcarvings (Makonde) for tourists (Jenkins et al., 2002).

Apart from having excellent timber, different part of this species such as leaves, roots and stem bark have diverse local medicinal uses in Africa including sacred 
rituals (Washa et al., 2012). The leaves are boiled in soup and drunk to relieve pain in joints (Kareru et al., 2008) dried leaves smoked as cigarette to treat asthma (Chigora et al., 2007), while treating bronchitis and inflammation in throat has also been reported (Lemmens, 2008). Combination made from its roots has been reported to treat abdominal pain, hernia, gonorrhea as well as complications from abortions (Kiondo et al., 2014). The bark from its stems and roots are used as ant-diarrhea while smoke from its burning roots is inhaled to treat bronchitis and headache (Kiondo et al., 2014). The bark of $D$. melanoxylon has also been used traditionally for cleaning wounds while the roots have been used to alleviate abdominal pains, as an anthelmintic and as a part of preparation for the treatment of gonorrhoea (Kokwaro, 1976).

Many modern drugs have been reported to show resistance in the treatment of bacterial and fungal infections. These modern drugs, apart from showing resistance to the bacterial and fungal infections they are also more expensive (Levy and Marshall, 2004; Norrby et al., 2005; Khan et al, 2009). At the same time, most of the African population lives below the poverty line and cannot afford the expensive modern medicines. These challenges call for renewed strategies on treatment, especially in the development of new antimicrobials. According to the World Health Organization (WHO), medicinal plants can provide the best alternative source to obtain a variety of drugs (WHO, 2002).

The genus Dalbergia in which $D$. melanoxylon belongs has been shown to possess various pharmacological activities including analgesic, antipyretic, antiinflammatory (Kale et al., 2007; Misar et al., 2005). With scant information is available for antimicrobial activity of $D$. melanoxylon, little has been done in evaluation of antimicrobial activity using different solvent extracts for the different plant parts. Therefore this study aimed at evaluating the antimicrobial activities of different solvent extracts for stem bark, roots and leaves of D. melanoxylon, Information obtained from antimicrobial activity is important for the conservation of the species for medicinal values and development of targeted approaches to help control antimicrobial resistance.

\section{Materials and Methods}

\section{Plant material collection}

The test plant was collected from Mbezi in Dar es Salaam located along $6^{\circ} 42^{\prime} 8^{\prime \prime} \mathrm{S}$ and $39^{\circ} 6^{\prime} 11^{\prime \prime} \mathrm{E}$, with altitude of 91.3 meters. The authenticity of the species was identified at the Herbarium in the Department of Botany, University of Dar es Salaam and given a herbarium number 3721 . The plant parts used were the leaves, stem and roots which were washed by tap water to remove dust and soil, and then allowed to dry under the shade. The plant materials were pounded to fine powder using motor and pestle.

\section{Plant parts extraction}

Plant parts namely roots, stem bark and leaves were separately washed with running tape water four times and were cut into small pieces which were rinsed with distilled water and air dried for five days. The dried materials were placed in hot air oven at 50 ${ }^{0} \mathrm{C}$ for three days. The dried pieces of root and stem were separately ground into fine uniform powder using a Thomas- Willey milling machine. Then $40 \mathrm{gm}$ of roots stem bark and leaves were separately extracted with $150 \mathrm{ml}$ of solvents serially extracted by 
using petroleum ether, chloroform, methanol and aqueous in the increasing order of their polarity for 48 hours. The extraction was carried out by cold maceration process. The extracts were filtered using Whatman filter paper No. 1. The petroleum ether, chloroform, methanol and aqueous filtrates were separately collected in the three different beakers and concentrated in room temperature with ceiling fan for 24 hours to obtain crude extracts. The aqueous filtrates were concentrated in rotary evaporator at 50 ${ }^{0} \mathrm{C}$ for 3 hours to obtain crude extracts.

\section{Test microorganisms and inoculums preparation}

The test microorganisms were obtained from University of Dar es Salaam in the department of Molecular Biology and Biotechnology (MBB). The standard strains of bacteria tested were Staphylococcus aureus (ATCC25923) and Eschericia coli (DSM1103). And the standard strain of fungi tested was Candida albicanas (ATCC9002).

Clotrimazole and Gentamycin were used as a positive control for fungi and bacteria respectively and Dimethyl sulphoxide (DMSO) was used as a negative control. All strains were sub-cultured onto Sabouraud Dextrose Agar (SDA) to ensure purity and viability. Inoculum was prepared by picking colonies from a 24 hour old culture and was suspended in $5 \mathrm{ml}$ of sterile $0.145 \mathrm{~mol} / \mathrm{L}$ saline (8.5g/L Nacl; $0.85 \%$ saline).

The resulting suspension was vortexed for $15 \mathrm{sec}$ and its turbidity was adjusted visually with turbidity of $0.5 \mathrm{McFarland}$ standards. This yielded a yeast stock suspension of 1.5 x $10^{-6}$ cells per $\mathrm{mL}$. McFarland standard was prepared by adding $0.5 \mathrm{~mL}$ of $0.048 \mathrm{M}$ $\mathrm{BaCl}_{2}\left(1.17 \% \mathrm{w} / \mathrm{v} \mathrm{BaCl}_{2}\right)$ to $99.5 \mathrm{~mL}$ of $0.18 \mathrm{M} \mathrm{H}_{2} \mathrm{SO}_{4}(1 \% \mathrm{v} / \mathrm{v})$ with constant stirring.

\section{Agar Well-Diffusion Assay and antimicrobial test}

Antimicrobial activity was determined by using the agar well diffusion method. Each Petri dish containing Multer-Hinton agar medium was inoculated with one microbial strain by scattering the suspension of the organism with a bended tip sterile glass rod. In each plate wells were made at equal distances using sterile cork borer. Five different concentrations $(50,100,150,200$ and $250 \mathrm{mg} / \mathrm{ml}$ ) of each prepared petroleum ether, chloroform, methanol and aqueous extracts were used for assessing the presence of zone diameter of inhibition. The concentrations were prepared by dissolving the weight of obtained crude extracts in dimethyl sulphoxide (DMSO) to get the different concentration $(\mathrm{mg} / \mathrm{ml})$. For the different concentrations of the extracts the volume of $50 \mu \mathrm{l}$ were added to fill the bore holes. The negative control was prepared by putting $50 \mu \mathrm{l}$ of DMSO in one of the bored holes. The positive control was prepared by putting $25 \mu \mathrm{g} / \mathrm{ml}$ gentamicin and clotrimazole for antibacterial activity and antifungal activity respectively in one of the bored hole for each one. One hour of prediffusion time allowed, after which the plates were incubated at $37{ }^{\circ} \mathrm{C}$ for the antibacterial activity and $31^{\circ} \mathrm{C}$ for the antifungal activity for 18 to 24 hours. Evaluation of antimicrobial activity was done through measuring diameter of the zone of inhibition and the average diameter in millimeter for each sample was calculated

\section{Phytochemical analysis}

Powdered 20g Dalbegia melanoxylon plant parts namely root barks stem barks and leaf weighed into separate conical flasks. To each of these flasks, $250 \mathrm{ml}$ of one of the following solvents was added (pet ether, chloroform, methanol or distilled water) and 
then boiled. Then the solution was filtered using whatman filter paper no.1 The resulting plant filtrates was used for phytochemical screening for secondary metabolites. The presence of qualitative phytochemical such as alkaloids, flavonoids, saponins, steroids and tannins were tested.

\section{Test for Alkaloids}

The presence of alkaloids in extracts was tested by using Wagner reagent that was prepared by dissolving $2 \mathrm{~g}$ of iodine and $6 \mathrm{~g}$ of potassium iodide in $100 \mathrm{ml}$ of water as described by (Mamta and Jyoti, 2012). Two milliliters of Wagner reagents were added to $2 \mathrm{ml}$ of extracts. The formation of reddish brown precipitate indicated the presence of alkaloids.

\section{Test for Steroids}

Test for steroids was done according to the method described by Mohammad, (2013) with modification. The plant extracts $(1 \mathrm{ml})$ was taken in a test tube and dissolved with chloroform $(10 \mathrm{ml})$ then equal volume of concentrated $\mathrm{H}_{2} \mathrm{SO}_{4}$ was added to the test tube by sides. The upper layer in the test tube appears red and Sulphuric acid layer showed yellow with green fluorescence, which indicated the presence of steroids.

\section{Test for Flavonoids}

A stock solution $(2 \mathrm{ml})$ was taken in a test tube and 2-3 drops of dilute $\mathrm{NaOH}$ was added as per (Mohammad et al., 2013). An intense yellow colour was appear in the test tube. The solution became colourless when few drops of dilute $\mathrm{H}_{2} \mathrm{SO}_{4}$ was added confirming the presence of flavonoids.

\section{Test for Saponins}

Two grams ( $2 \mathrm{~g})$ of the powdered sample was boiled in $20 \mathrm{ml}$ of distilled water in a water bath and filtered as previously described by (Doherty, et al., 2010). To the filtered sample $(10 \mathrm{ml})$, about $(5 \mathrm{ml}$ distilled water) will be added, shaken vigorously and observed for a stable persistent frothing for 25 minutes.

\section{Test for Tannins}

Test for tannins was done according to (Doherty et al., 2010) with some modification. Dried powdered sample $(0.5$ g) was boiled in water $(20 \mathrm{ml})$ in a test tube and then filtered. One milliliters of $0.1 \%$ $\left(\mathrm{FeCl}_{3}\right)$ Ferric Chloride $(0.01 \mathrm{Mol} / \mathrm{dm} 3)$ added to $2 \mathrm{ml}$ of each extract sample. Brownish green colorations was indicated the presence of tannins.

\section{Statistical Analysis}

All the experiments were conducted in triplicate and statistical analysis of the data was performed by analysis of variance (ANOVA) using SPSS 20 software. All data were presented as mean values and standard mean errors for the replicate sets of experiments in each case.

\section{Results and Discussion}

\section{Results for zone of inhibitions}

Variation in zone of inhibition for the different solvents existed as shown (Tables 1 to 3) for the mean zone of inhibition with standard error mean for the different concentration used for different plant parts of D. melanoxylon. At higher concentration the inhibition zone was significantly higher than at low concentration. Except for the positive control, the use of petroleum as solvent extracts didn't show zone of inhibition for root, stem and leaf extracts of D. melanoxylon. For chloroform extract the diameter for inhibition zone ranged from $6.06 \pm 0.76 \mathrm{~mm}$ for $C$. albicans (ATCC 
9002) stem extract at concentration 50 $\mathrm{mg} / \mathrm{ml}$ to $16.68 \pm 0.58 \mathrm{~mm}$ at , concentration $250 \mathrm{mg} / \mathrm{ml} \mathrm{C}$. albicans (ATCC 9002) for the leaf extract (Table 1).

Generally stem and leaf chloroform extracts showed high inhibition zone for $C$. albicans (ATCC 9002) compared to the inhibition zone revealed for $S$. aureus (ATCC25923) and $C$. albicans (ATCC 9002) (Table 1). Thus the results reveal that stem and leaf chloroform extracts are effective for antifungal activity compared to the antibacterial activity.

Results for stem root and leaf methanol extract is shown in table 2. Generally stem and leaf methanol extracts had high diameter for inhibition zone for all tested microbes compared to the root extract. For the antifungal activity, stem extracts had the highest zone of inhibition $19.38 \pm 1.53 \mathrm{~mm}$ at $250 \mathrm{mg} / \mathrm{ml}$ concentration for $S$. aureus (ATCC25923) while for the antibacterial activity the leaf extract had the highest zone of inhibition of $18.67 \pm 0.88$ for $C$. albicans (ATCC 9002) at $250 \mathrm{mg} / \mathrm{ml}$ concentration (Table 2). Root methanol extracts showed low inhibition zone for all tested microbes compared to other plant parts thus revealing root has less effective antimicrobial activity compared to the roots and leaf parts of $D$. melanoxylon.

Results for aqueous stem bark, root and leaf extracts of $D$. melanoxylon is shown in table 3. At higher concentration the inhibition zone was significantly higher than at low concentration. The highest inhibition zone was $15.67 \pm 0.33 \mathrm{~mm}$ for E.coli (DSM1103) leaf extract at concentration $250 \mathrm{mg} / \mathrm{ml}$ followed by $14.67 \pm 0.67$ for $S$. aureus (ATCC25923) also for the leaf extract (Table 3). Generally all plant parts for aqueous extracts showed good inhibition zone for all tested microbes. The results reveal that $D$. melanoxylon aqueous extracts are effective for to the antimicrobial activity.

\section{Comparison for the different solvent and plant part extracts}

The antimicrobial activity of different solvent extracts done by comparing the average zones of inhibition shown by different solvent extracts is indicated in figure 1. Although the solvents didn't differ significantly but in average both methanol and aqueous revealed highest zone of inhibition indicating high antimicrobial activity for E.coli (DSM1103), S. aureus (ATCC25923) and $C$. albicans (ATCC 9002) compared to petroleum ether and chloroform. In figure 2 the antimicrobial activity for the different plant parts tested is revealed, the results indicates that extracts from the stem and leaf had good antimicrobial activity for all tested microbes compared to root extracts of $D$. melanoxylon.

The overall results obtained showed that the methanol extract exhibited strongest antimicrobial activity. The chloroform extract showed significant antifungal activity but was not significantly active against bacteria especially $S$. aureus. The aqueous extract exhibited antibacterial and antifungal activity but not effective as methanol. The petroleum ether showed no antimicrobial activity. On the other hand, the results of the study reveals that all the three parts of the tested plant extracts inhibit the growth of selected bacteria and fungi but the stem bark showed strongest inhibitory growth of bacteria and fungi on the plate. This is because of the presence of bioactive compounds such as alkaloids, flavonoids and tannins in which flavonoids possess many biochemical properties.

The active principles responsible for the therapeutic effects of medicinal plants are phytochemicals, typically secondary metabolites, including but not limited to alkaloids, steroids, flavonoids, terpenoids 
and tannins (Nonita et al., 2010). The presence of these phytochemicals in polar extracts such methanol and aqueous extracts being responsible for antifungal activity against has also previously been reported in other species when compared to other solvent extracts (Panda et al., 2010).

The reason for this slight difference may be attributed to the solubility level of the phytoconstituents in the solvents. It means that the methanol and aqueous extracts dissolved more active ingredients compared to other solvents. Such variation could as well be attributed to the variation in phytochemical composition in the tested plants parts in which one part either leaves, stem or roots having more phytoconstituents than the other parts as reported of others species in Euphobiaceae (Igbinosa et al., 2009; Kamba and Hassan, 2010).

Although all tested plant parts indicated the antimicrobial activity, however for conservation D. melanoxylon as economically important species the use of roots and stem barks should be discouraged. Harvesting medicinal plants through root excavation and bark striping can be very devastating and pose a serious threat to the plant survival (Signorini et al., 2009; Amri and Kisangau, 2012). Currently $D$. melanoxylon is categorized as Lower Risk/near threatened (LR/nt) species on the Red List of threatened species on the International Union for conservation of Nature (IUCN), which means its conservation is very important (World Conservation Monitoring Centre, 1998). Genetic diversity of the species is being lost rapidly due to the process of deforestation, which has reduced the size of natural populations and eliminated local populations (Amri et al., 2009). Moreover, this species has serious reproductive limitations, both asexually and sexually with very low germination capacity (Amri et al., 2008). Consevation of the species should be encourage not only for ethnomedicinal value but also as nitrogen fixing species that improves soil fertility and helps maintain soil stability so that could therefore be maintained on farms as this helps the plant to get available nitrogen with other crops (Amri et al., 2009; Washa et al., 2012).

\section{Qualitative phytochemical analysis}

Evaluation of phytochemicals revealed the presence alkaloids, steroids, flavonoids, saponins and tannins in different plant parts depending on the type solvent used (Tables $4 \mathrm{a}, \mathrm{b}, \mathrm{c}$ and d). For petroleum ether extracts only steroids and alkaloids were found. The presence of most of the constituent in most polar extracts namely methanol and aqueous extracts compared with nonpolar extracts mainly petroleum ether and chloroform is an indication of the high antimicrobial activity revealed by these solvent extracts.

On related with phytochemical screening in D. melanoxylon the flavonoids and tannins were found similar to other studies which showed that neoflavanoids, phenolic and tannins were obtained where tannins and neoflavanoids are the potent antioxidant and free radical scavenger which prevent oxidative cell damage and also have strong antimicrobial activities (Khan et. al., 2014). The active principles responsible for the therapeutic effects of medicinal plants are phytochemicals, typically secondary metabolites, including but not limited to alkaloids, steroids, flavonoids, terpenoids and tannins (Nonita and Mylene, 2010). The occurrence of isoflavones, isoflavanones, neoflavones, sterols, anthraquinones, cinnamyl esters and triterpenes in the genus Dalbergia in which $D$. melanoxylon belongs has previously been reported (Vasudeva et al., 2009). 
Table.1 Mean zone of inhibition (in $\mathrm{mm}$ ) of chloroform for stem, root and leaf extracts of $D$. melanoxylon.

\begin{tabular}{|c|c|c|c|c|}
\hline \multirow{2}{*}{$\begin{array}{ll}\text { Plant } & \text { part } \\
\text { extract } & \end{array}$} & \multirow{2}{*}{$\begin{array}{l}\text { Crude } \\
\text { concentration } \\
(\mathrm{mg} / \mathrm{ml})\end{array}$} & \multicolumn{3}{|c|}{ Test organisms } \\
\hline & & \begin{tabular}{|l} 
E.coli \\
(DSM1103)
\end{tabular} & $\begin{array}{l}\text { S. aureus } \\
\text { (ATCC25923) }\end{array}$ & $\begin{array}{l}\text { C. albicans } \\
\text { (ATCC9002) }\end{array}$ \\
\hline \multirow[t]{6}{*}{ Stem } & 50 & $6.33 \pm 0.33$ & $6.06 \pm 0.76$ & $11.34 \pm 1.33$ \\
\hline & 100 & $6.76 \pm 0.88$ & $7.14 \pm 0.84$ & $10.67 \pm 1.33$ \\
\hline & 150 & $7.33 \pm 0.67$ & $7.33 \pm 0.33$ & $11.64 \pm 0.88$ \\
\hline & 200 & $8.86 \pm 0.67$ & $7.43 \pm 0.88$ & $15.67 \pm 0.33$ \\
\hline & 250 & $12.33 \pm 1.20$ & $9.52 \pm 0.33$ & $17.54 \pm 1.45$ \\
\hline & Negative control & $26.8 \pm 0.37$ & $27.2 \pm 1.02$ & $23.6 \pm 0.40$ \\
\hline \multirow[t]{6}{*}{ Root } & 50 & $6.33 \pm 0.33$ & $0.00 \pm 00$ & $6.00 \pm 0.58$ \\
\hline & 100 & $8.34 \pm 0.33$ & $6.53 \pm 0.33$ & $9.04 \pm 0.33$ \\
\hline & 150 & $9.67 \pm 0.33$ & $7.36 \pm 0.33$ & $10.67 \pm 0.33$ \\
\hline & 200 & $10.84 \pm 0.88$ & $8.82 \pm 0.88$ & $11.98 \pm 0.67$ \\
\hline & 250 & $11.33 \pm 0.33$ & $8.33 \pm 1.20$ & $12.35 \pm 0.42$ \\
\hline & Negative control & $26.8 \pm 0.37$ & $27.2 \pm 1.02$ & $23.6 \pm 0.40$ \\
\hline \multirow[t]{6}{*}{ Leaf } & 50 & $6.35 \pm 0.33$ & $0.00 \pm 00$ & $11.67 \pm 0.67$ \\
\hline & 100 & $8.32 \pm 1.20$ & $4.28 \pm 00$ & $12.32 \pm 1.15$ \\
\hline & 150 & $8.33 \pm 0.33$ & $5.46 \pm 0.67$ & $12.67 \pm 0.88$ \\
\hline & 200 & $9.64 \pm 0.33$ & $6.33 \pm 0.88$ & $14.67 \pm 1.45$ \\
\hline & 250 & $10.24 \pm 0.58$ & $8.86 \pm 1.20$ & $16.68 \pm 0.58$ \\
\hline & Negative control & $26.8 \pm 0.37$ & $27.2 \pm 1.02$ & $23.6 \pm 0.40$ \\
\hline
\end{tabular}

Table.2 Mean zone of inhibition (in $\mathrm{mm}$ ) of methanol for stem, root and leaf extracts of $D$. melanoxylon

\begin{tabular}{|l|l|l|l|l|}
\hline \multirow{3}{*}{$\begin{array}{l}\text { Plant part } \\
\text { extract }\end{array}$} & $\begin{array}{l}\text { Crude concentration } \\
(\mathrm{mg} / \mathrm{ml})\end{array}$ & \multicolumn{3}{|c|}{ Test organism } \\
\cline { 3 - 5 } & & $\begin{array}{l}\text { E.coli } \\
(\mathrm{DSM} 1103)\end{array}$ & $\begin{array}{l}\text { S.aureus } \\
(\text { ATCC25923) }\end{array}$ & $\begin{array}{l}\text { C.albicans } \\
\text { (ATCC9002) }\end{array}$ \\
\hline \multirow{5}{*}{ Stem } & 50 & $7.67 \pm 0.67$ & $8.12 \pm 0.58$ & $11.67 \pm 0.67$ \\
\cline { 2 - 5 } & 100 & $9.67 \pm 0.88$ & $10.33 \pm 1.45$ & $12.00 \pm 0.58$ \\
\cline { 2 - 5 } & 150 & $11.67 \pm 0.33$ & $11.78 \pm 0.88$ & $14.33 \pm 0.88$ \\
\cline { 2 - 5 } & 200 & $12.67 \pm 0.33$ & $12.33 \pm 1.20$ & $16.44 \pm 0.58$ \\
\cline { 2 - 5 } & 250 & $14.67 \pm 0.33$ & $14.82 \pm 1.15$ & $19.38 \pm 1.53$ \\
\cline { 2 - 5 } & Negative control & $27.00 \pm 0.71$ & $28.40 \pm 0.51$ & $23.80 \pm 0.37$ \\
\hline \multirow{5}{*}{ oot } & 50 & $6.67 \pm 0.67$ & $8.00 \pm 1.53$ & $4.68 \pm 0.67$ \\
\cline { 2 - 5 } & 100 & $9.00 \pm 0.58$ & $7.67 \pm 0.67$ & $5.34 \pm 0.67$ \\
\cline { 2 - 5 } & 150 & $9.33 \pm 1.20$ & $5.67 \pm 1.20$ & $5.74 \pm 0.88$ \\
\cline { 2 - 5 } & 200 & $11.67 \pm 0.88$ & $10.33 \pm 2.40$ & $6.32 \pm 0.33$ \\
\cline { 2 - 5 } & 250 & $12.00 \pm 1.00$ & $12.00 \pm 1.15$ & $6.67 \pm 0.33$ \\
\cline { 2 - 5 } & Negative control & $27.00 \pm 0.71$ & $28.40 \pm 0.51$ & $23.80 \pm 0.37$ \\
\hline \multirow{5}{*}{ Leaf } & 50 & $10.33 \pm 0.88$ & $9.33 \pm 1.20$ & $10.00 \pm 1.00$ \\
\cline { 2 - 5 } & 100 & $9.33 \pm 0.67$ & $9.00 \pm 1.00$ & $8.42 \pm 2.08$ \\
\cline { 2 - 5 } & 150 & $10.21 \pm 0.67$ & $8.67 \pm 1.33$ & $9.67 \pm 0.88$ \\
\cline { 2 - 5 } & 200 & $11.48 \pm 0.67$ & $16.33 \pm 0.33$ & $11.24 \pm 0.58$ \\
\cline { 2 - 5 } & 250 & $12.67 \pm 0.33$ & $18.67 \pm 0.88$ & $13.68 \pm 0.88$ \\
\cline { 2 - 5 } & Negative control & $27.00 \pm 0.71$ & $28.40 \pm 0.51$ & $23.80 \pm 0.37$ \\
\hline
\end{tabular}


Table.3 Mean zone of inhibition (in $\mathrm{mm}$ ) of aqueous for stem, root and leaf extracts of $D$. melanoxylon

\begin{tabular}{|l|l|l|l|l|}
\hline \multirow{3}{*}{$\begin{array}{l}\text { Plant } \begin{array}{l}\text { part } \\
\text { extract }\end{array} \\
(\mathrm{mg} / \mathrm{ml})\end{array}$} & \multicolumn{3}{|c|}{ Tested organism } \\
\cline { 2 - 5 } & $\begin{array}{l}\text { E.coli } \\
(\mathrm{DSM} 1103)\end{array}$ & $\begin{array}{l}\text { S.aureus } \\
(\text { ATCC25923) }\end{array}$ & $\begin{array}{l}\text { C.albicans } \\
\text { (ATCC9002) }\end{array}$ \\
\hline \multirow{5}{*}{ Stem } & 50 & $7.12 \pm 0.67$ & $9.67 \pm 0.33$ & $9.22 \pm 0.58$ \\
\cline { 2 - 5 } & 100 & $9.56 \pm 0.88$ & $8.78 \pm .120$ & $8.45 \pm 0.67$ \\
\cline { 2 - 5 } & 150 & $10.43 \pm 0.33$ & $10.86 \pm 0.34$ & $10.67 \pm 0.88$ \\
\cline { 2 - 5 } & 200 & $11.67 \pm 0.33$ & $12.42 \pm 0.67$ & $11.45 \pm 0.72$ \\
\cline { 2 - 5 } & 250 & $12.32 \pm 0.33$ & $13.64 \pm 0.58$ & $12.84 \pm 0.33$ \\
\cline { 2 - 5 } & Negative control & $27.20 \pm 0.58$ & $28.40 \pm 0.75$ & $24.00 \pm 0.45$ \\
\hline \multirow{5}{*}{ Root } & 50 & $8.67 \pm 0.33$ & $7.68 \pm 0.69$ & $4.67 \pm 0.24$ \\
\cline { 2 - 5 } & 100 & $7.33 \pm 1.20$ & $11.08 \pm 0.58$ & $6.72 \pm 0.33$ \\
\cline { 2 - 5 } & 150 & $10.62 \pm 0.33$ & $9.33 \pm 0.33$ & $7.38 \pm 0.88$ \\
\cline { 2 - 5 } & 200 & $11.33 \pm 0.67$ & $10.74 \pm 0.58$ & $7.86 \pm 0.33$ \\
\cline { 2 - 5 } & 250 & $12.00 \pm 1.24$ & $12.82 \pm 0.88$ & $9.12 \pm 0.33$ \\
\cline { 2 - 5 } & Negative control & $27.20 \pm 0.58$ & $28.40 \pm 0.75$ & $24.46 \pm 0.45$ \\
\hline \multirow{5}{*}{ Leaf } & 50 & $6.67 \pm 0.33$ & $7.32 \pm 0.67$ & $5.46 \pm 0.33$ \\
\cline { 2 - 5 } & 100 & $8.12 \pm 0.58$ & $8.67 \pm 1.20$ & $7.67 \pm 0.67$ \\
\cline { 2 - 5 } & 150 & $11.67 \pm 0.33$ & $9.33 \pm 1.45$ & $8.86 \pm 0.88$ \\
\cline { 2 - 5 } & 200 & $13.67 \pm 0.33$ & $12.00 \pm 0.58$ & $9.68 \pm 0.67$ \\
\cline { 2 - 5 } & 250 & $15.67 \pm 0.33$ & $14.67 \pm 0.67$ & $14.33 \pm 0.88$ \\
\cline { 2 - 5 } & Negative control & $27.20 \pm 0.58$ & $28.40 \pm 0.75$ & $24.64 \pm 0.45$ \\
\hline
\end{tabular}

Table.4a Detected phytochemical presence in petroleum ether crude extract

\begin{tabular}{|l|l|l|l|l|l|}
\hline \multirow{2}{*}{$\begin{array}{l}\text { Plant } \\
\text { part }\end{array}$} & \multicolumn{6}{|l|}{ Detected type of phytochemical component } \\
\cline { 2 - 6 } & Alkaloids & Steroids & Flavonoids & Saponins & Tannins \\
\hline Stem & + & + & - & - & - \\
\hline Root & + & + & - & - & - \\
\hline Leaves & - & - & - & - & - \\
\hline
\end{tabular}

Key: $\quad+=$ Present $\quad-=$ Absent

Table.4b Detected phytochemical presence in chloroform crude extract

\begin{tabular}{|l|l|l|l|l|l|}
\hline \multirow{2}{*}{$\begin{array}{l}\text { Plant } \\
\text { part }\end{array}$} & \multicolumn{2}{|l|}{ Detected type of phytochemical component } & \multicolumn{2}{l|}{ Tannins } \\
\cline { 2 - 6 } & Alkaloids & Steroids & Flavonoids & Saponins & + \\
\hline Stem & + & + & + & - & - \\
\hline Root & + & - & + & - & + \\
\hline Leaves & - & - & + & - & \\
\hline
\end{tabular}

Key: $\quad+=$ Present $\quad-=$ Absent 
Table.4c Detected phytochemical presence in methanol crude extract

\begin{tabular}{|l|c|c|c|c|c|}
\hline \multirow{2}{*}{$\begin{array}{l}\text { Plant } \\
\text { part }\end{array}$} & \multicolumn{6}{|l|}{ Detected type of phytochemical component } \\
\cline { 2 - 6 } & Alkaloids & Steroids & Flavonoids & Saponins & Tannins \\
\hline Stem & + & - & + & - & + \\
\hline Root & + & - & + & + & + \\
\hline Leaves & + & + & + & - & + \\
\hline
\end{tabular}

Key: $\quad+=$ Present $\quad-=$ Absent

Table.4d Detected phytochemical presence in aqueous crude extract

\begin{tabular}{|l|l|l|l|l|l|}
\hline \multirow{2}{*}{$\begin{array}{l}\text { Plant } \\
\text { part }\end{array}$} & \multicolumn{6}{|l|}{ Detected type of phytochemical component } \\
\cline { 2 - 6 } & Alkaloids & Steroids & Flavonoid & Saponins & Tannins \\
\hline Stem & + & + & + & + & + \\
\hline Root & + & - & + & + & - \\
\hline Leaves & + & + & + & + & + \\
\hline
\end{tabular}

Key: $+=$ Present $\quad-=$ Absent

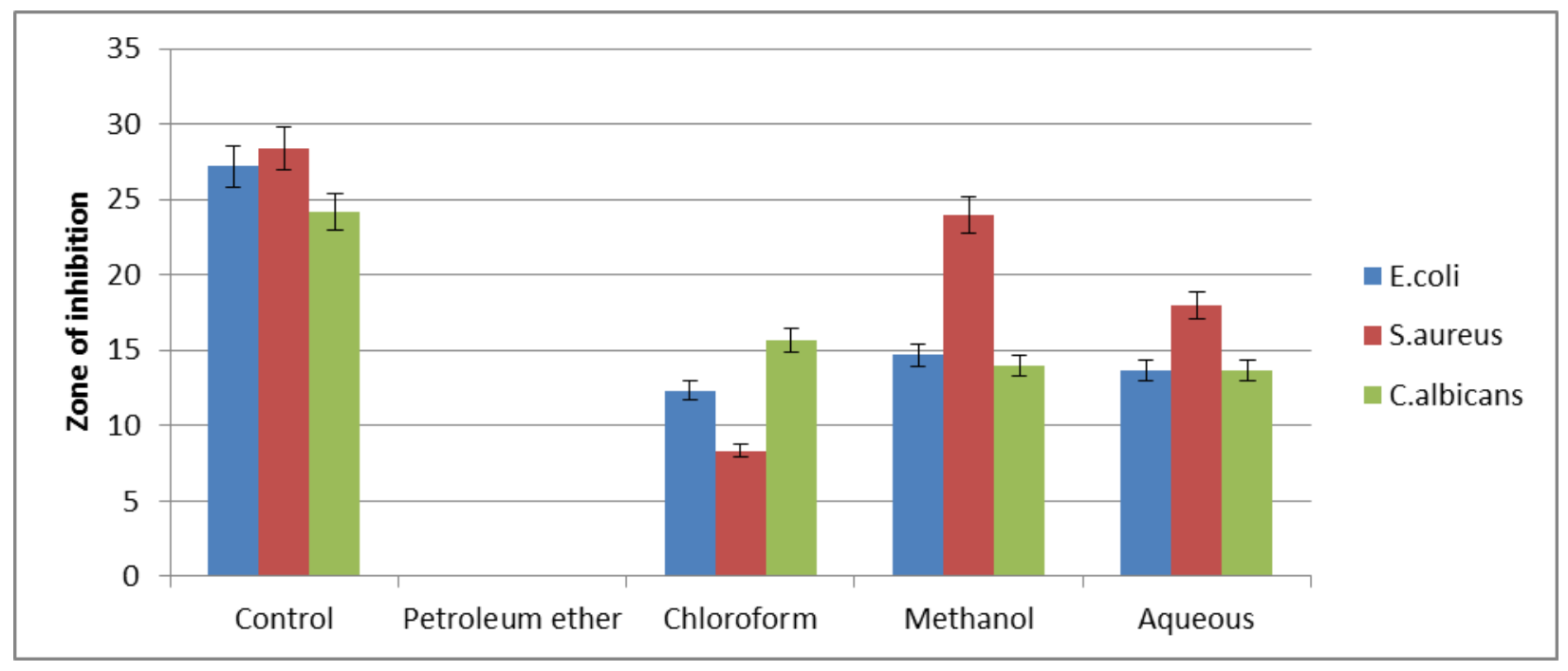

Fig.1 The effect of different solvent extracts against the tested microorganisms 


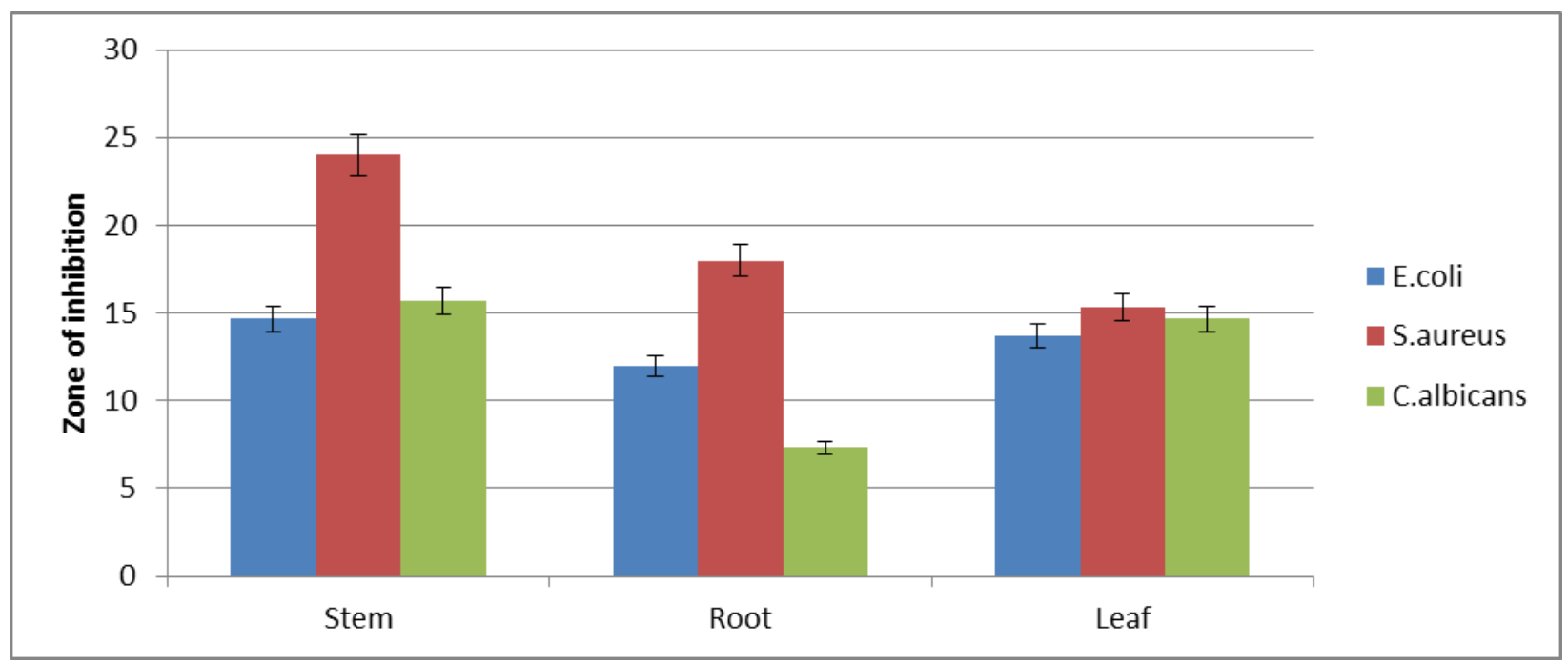

Fig.2 The effects of plant parts extracts against the tested microorganisms

The revealed the presence of phytochemical compounds in D. melanoxylon is an indication that the plant had biologically active compounds as secondary metabolites which exert antimicrobial activity through different mechanisms. Tannins have been found to form irreversible complexes with proline rich protein (Shimada, 2006) resulting in the inhibition of cell protein synthesis. Parekh and Chanda (2007) reported that tannins are known to react with proteins to provide the typical tanning effect which is important for the treatment of inflamed or ulcerated tissues. Flavonoids was another phytochemical constituent found in stem bark, root and leaf extracts of D. melanoxylon. Flavonoids have previously been reported to exhibit a wide range of biological activities like antimicrobial, antiinflammatory, anti- anti-allergic and antioxidant properties (Hodek et al., 2002).

In conclusion, study has revealed that $D$. melanoxylon root, stem bark and leaf extracts have antimicrobial activity. Stem bark of D. melanoxylon showed high inhibitory growth of bacteria and fungi strains compared to other plant parts. The revealed presence of phytochemical compound in different plant parts is an indication that the plant possess bioactive compounds which flavonoids act as antimicrobial agents. Methanol extract was the best for extraction this is because mostly methanol is used for extraction of various polar compounds but certain groups on nonpolar compounds are fairly soluble in methanol compared to other solvents. This study may serve as the primary platform for the further in-vivo studies; however, further research is necessary to determine the identity of the therapeutic compound within this plant also to determine their full spectrum of efficacy.

\section{References}

Amri, E., Kisangau, D.P. 2012. Ethnomedicinal Study of Plants Used in Villages around Kimboza Forest Reserve in Morogoro, Tanzania. $J$. Ethnobiol. Ethnomed., 8: 1.

Amri, E., Lyaruu, H. V. M., Nyomora, A. M. S.and Kanyeka, Z. L. (2008). Effect of timing of seed collection and provenance on seed viability and germination of Dalbergia melanoxylon. Bot. Res. J., 1: 82-88. 
Amri, E., Z.L. Kanyeka, H.V.M. Lyaruu and A.S. Nyomora. 2009. Evaluation of genetic diversity in Dalbergia elanoxylon populations using random amplified polymorphic DNA markers. Res. J. Cell and Mol. Biol., 3(2): 71-79.

Ball, S.M.J. 2004. Stocks and exploitation of East African blackwood Dalbergia melanoxylon: a flagship species for Tanzania's miombo woodlands? Oryx, 38(3): 266-272.

Chigora, P., Masocha, R., Mutenheri, F. 2007. The role of indigenous medicinal knowledge (IMK) in the treatment of ailments in rural Zimbabwe: the case of Mutirikwi communal lands. $J$. Sustainable Develop Africa, 9: 26-43.

Doherty, V.F., Olaniran, O.O. and Kanife, U.C. 2010. Antimicrobial Activities of Aframomum melegueta (Alligator Pepper). Int. J. Biol., 2(2): 126-131.

Hodek, P., Trefil, P., Stiborova, M. 2002. Flavonoids - Potent and versatile biologically active compounds interacting with cytochrome P450. Chemico-biological interactions, (1): 121.

Igbinosa, O.O., Igbinosa, E.O. and Aiyegoro, O.A. 2009. Antimicrobial activity and phytochemical screening of stem bark extracts from Jatropha curcas (Linn). African J. Pharmacy and Pharmacol., 3(2): 058-062.

Jenkins, M., Oldfield, S. and Aylett, T. 2002. International Trade in African Blackwood, Fauna \& Flora International.

Kale, M., Misar, A.V., Dave, V., Joshi, M., \& Mujumdar, A.M. 2007. Antiinflammatory activity of Dalbergia lanceolaria bark ethanol extract in mice and rats. J. ethnopharmacol., 112(2): 300-304.

Kamba, A.S. and Hassan, L.G. 2010. Phytochemical screening and antimicrobial activities of Euphorbia balsamifera leaves, stems and root against some pathogenic microorganisms. African J. Pharmacy and Pharmacol., 4(9): 645-652.

Kareru, P.G., Gachanja, A.N., Keriko, J.M., and Kenji, G.M. 2008. Antimicrobial activity of some medicinal plants used by herbalists in eastern province, Kenya. African J. Traditional, Complementary and alternative med., 5(1): 51-55.

Khan, R., Islam, B., Akram, M., Shakil, S., Ahmad, A. A., Ali, S. M., and Khan, A. U. 2009. Antimicrobial activity of five herbal extracts against multi drug resistant (MDR) strains of bacteria and fungus of clinical origin. Mol., 14(2): 586-597.

Kiondo, F., Feyissa, T., Ndakidemi, P. A. and Seth, M. 2014. In vitro propagation of Dalbergia melanoxylon Guill. \& Perr.: a multipurpose tree. American J. Res. Cотти., 2(11): 181-194.

Kokwaro, J.O. 1976. Medicinal Plants of East Africa, first ed. East African Literature Bureau, pp. 135.

Lemmens, R.H.M.J. 2008. Dalbergia melanoxylon Guill. and Perr. Plant Resources of Tropical Africa 7(1): Timbers 1. Edited by: Louppe D, OtengAmoako AA, Brink M., Wageningen: Prota Foundation, 202-207.

Levy, S.B., Marshall, B. 2004. Antibacterial resistance worldwide: causes, challenges and responses. Nature med., 10: S122-S129.

Mamta, S., Jyoti, S. 2012. Phytochemical screening of acorus calamus and lantana camara. Int. Res. J. Pharmacy, 5: 324326.

Misar, A.V., Kale, M., Joshi, M., and Mujumdar, A.M. 2005. Analgesic Activity of Dalbergia lanceolaria. Bark Extract in Swiss Albino Mice. Pharmaceutical Biol., 43(8): 723-725.

Mohammad RafiqKhan, Ranjini, R. 2013. Preliminary Phytochemical screening of 
seeds of psoralifolia, Int. Res. J. Pharmacy, 4: 1-12.

Nonita, P.P. and Mylene, M.U. 2010. Antioxidant and cytotoxic activities and phytochemical screening of four Philippine medicinal plants. J. Medi. Plants Res., 4: 407-414.

Norrby, S.R., Nord, C.E. and Finch, R. 2005. Lack of development of new antimicrobial drugs: a potential serious threat to public health. The Lancet Infect. Dis., 5(2): 115-119.

Panda, S.K., Brahma, S., and Dutta, S.K. 2010. Selective antifungal action of crude extracts of Cassia fistula L.: a preliminary study on Candida and Aspergillus species. Malaysian $J$. Microbiol., 6: 62-68.

Parekh, J., Chanda, S. 2007. In vitro antibacterial activity of crude methanol extract of Woodfordia fruticosa Kurz flower (Lythacease). Brazilian $J$. Microbiol., 38(2): 204-207.

Shimada, T. 2006. Salivary proteins as a defense against dietary tannins. $J$. Chem. Ecol., 32(6): 1149-1163.

Signorini, M.A., Piredda, M., Bruschi, P. 2009. Plants and traditional knowledge:
An ethnobotanical investigation on Monte Ortobene (Nuoro, Sardinia). J. Ethnobiol. Ethnomed., 5: 6.

Vasudeva, N., Vats, M., Sharma, S.K. and Sardana, S. 2009. Chemistry and biological activities of the genus Dalbergia-A review. Pharmacognosy Rev., 3(6): 307-3014.

Washa, W.B.A., Nyomora, A.M.S. and Lyaruu, H.M.V. 2012. Improving propagation success of $\mathrm{D}$. melanoxylon (African blackwood) in Tanzania (II): Rooting ability of stem and root cuttings of Dalbergia melanoxylon (African blackwood) in response to rooting media sterilization in Tanzania. Tanzania J. Sci., 38(1): 43-53.

WHO. 2002. Traditional Medicine: Growing Needs and Potential. WHO Policy Perspectives on Medicines. World Health Organization, Geneva 2002.

World Conservation Monitoring Centre. 1998. Dalbergia melanoxylon. In: IUCN 2006. 2006 IUCN Red Lis $t$ of Th reatened Species . <www.iu $\mathrm{c} \mathrm{n}$ re $\mathrm{d}$ lis $\mathrm{t}$ $.0 \mathrm{rg}>$. Downloaded on 08November 2006.

\section{How to cite this article:}

Amri, E., and Juma, S. 2016. Evaluation of Antimicrobial Activity and Qualitative Phytochemical Screening of solvent extracts of Dalbergia melanoxylon (Guill. \& Perr.). Int.J.Curr.Microbiol.App.Sci. 5(7): 412-423. doi: http://dx.doi.org/10.20546/ijcmas.2016.507.045 